\section{Establishment and Survival of Endophyte-infected and Uninfected Tall Fescue and Perennial Ryegrass Overseeded into Existing Kentucky Bluegrass Lawns in Northeastern North America}

\author{
Sophie Rochefort ${ }^{1}$ and Yves Desjardins \\ Centre de Recherche en Horticulture, Pavillon de l'Envirotron, Université \\ Laval, Sainte-Foy, Quebec, G1K 7P4, Canada \\ David J. Shetlar \\ Ohio State University, Department of Entomology, 1991 Kenny Road, \\ Columbus, $\mathrm{OH} 43210$
}

\section{Jacques Brodeur}

Institut de Recherche en Biologie Végétale, Département des Sciences Biologiques, Université de Montréal, 4101 rue Sherbrooke est, Montréal, Quebec, H1X 2B2, Canada

Additional index words. Neotyphodium, endophyte, winter survival, tall fescue, perennial ryegrass

\begin{abstract}
Overseeding of tall fescue and perennial ryegrass into pre-existing stands of kentucky bluegrass is viewed as a strategy to enhance the quality and durability of turfgrass lawns. In a 3-year study, the authors investigated the winter survival and establishment of tall fescue ('Bonsai 2000'), with or without Neotyphodium coenophialum, and perennial ryegrass ('Palmer III'), with or without $N$. lolii, in the province of Quebec, Canada $\left(\approx \mathrm{lat}_{\mathrm{a}}, \mathrm{54}^{\circ} \mathrm{N}\right)$, a region characterized by rigorous winter conditions. Grass species were overseeded in June 2003 at two different rates $\left(90\right.$ and $\left.180 \mathrm{~kg} \cdot \mathrm{ha}^{-1}\right)$, in experimental plots from two bioclimatological conditions: Quebec City and Boucherville. Turfgrass establishment and endophyte infection were evaluated during the following two spring and fall periods. Both tall fescue and perennial ryegrass had the capacity to establish and survive winter conditions, but performed best when snow cover was thick and present throughout the winter. The proportion of overseeded plants in the turfgrass stand rarely reached $30 \%$ over the years. Although the proportion of tall fescue and perennial ryegrass plants was much reduced in the spring, some tillers survived and were able, later in the season, to compete with kentucky bluegrass as tall fescue and perennial ryegrass populations returned to initial establishment populations each summer in mixed stands. Overwinter endophyte survival was species specific, with $N$. lolii being able to survive the cold winter but not $N$. coenophialum, which had a low percent of infection. For the perennial ryegrass- $N$. lolii association, competition with kentucky bluegrass is a primary factor limiting the increase over time in the proportion of endophyte-infected plants in a turfgrass mixture. Seeding rates did not influence the establishment of either grass species.
\end{abstract}

Mixed stands of grass species are used increasingly to enhance the quality and durability of turfgrass lawns. Mixtures of complementary grass species may improve turf quality because of greater tolerance to abiotic (cold, heat, drought) and biotic (arthropod pests, plant diseases, weed invasion) stresses compared with a single species (Beard, 1973; Brede and Duich, 1984; Coll and Bottrell, 1994). Tall fescue (Festuca arundinacea Shreb.) and perennial ryegrass (Lolium perenne L.) are the most promising species to be used with kentucky bluegrass (Poa pratensis
L.), the most extensively planted grass as monostands in northeastern North America (Turgeon, 1991).

The aggressive rhizomatous growth habit of kentucky bluegrass provides very dense and uniform lawns over the growing season (Beard, 1973). However, kentucky bluegrass is susceptible to many insect pests and diseases (Tashiro, 1987). The introduction of turf-type perennial ryegrass and tall fescue in an established kentucky bluegrass lawn could increase plant diversity and likely enhance resistance to environmental stresses. Tall fescue has an excellent wear tolerance and is usually integrated on playgrounds and sport fields. Perennial ryegrass, because of its high rate of establishment and tillering ability, is included in seed mixtures to provide rapid groundcover before germination of kentucky bluegrass seeds (Turgeon, 1991).

Turf management may also be improved through the addition of endophytic grasses in grass mixtures (Funk et al., 1993; Hull et al., 1994). In the context of a complete ban of pesticide usage enforced in Quebec, overseeding of endophytic tall fescue and perennial ryegrass may constitute an alternative if they have the capacity to compete with kentucky bluegrass in the swards. Neotyphodium spp. endophytes develop nonpathogenic, systemic, and usually intercellular symbiotic associations with several cool-season grasses such as perennial ryegrass and tall fescues (Malinowski et al., 2005; Marshall et al., 1999), but not with kentucky bluegrass. Neotyphodium is an asexual form of grass endophyte that is transmitted vertically and maternally by hyphae growing into seeds (Breen, 1994). The level of endophyte infection in plants is therefore based on percentage viable infection in the seeds. Neotyphodium-infected plants may benefit from enhanced growth and vigor (Latch and Christensen, 1985), increased tolerance to climatic factors such as drought and high temperatures (Bacon, 1993; Belesky et al., 1987), reduced susceptibility to diseases, and reduced susceptibility to insect infestations (Breen, 1994; Carrière et al., 1998; Richmond and Shetlar, 2000).

Although turfgrass mixtures have potential for better overall quality than any one component species (Dunn et al., 2002), the establishment and survival of each grass species in the sward, together with the association with endophytes, are likely to differ over time. Indeed, the composition of a lawn is determined by the intrinsic competitiveness of the different grass species, as well as their response to several other factors: climatic conditions, cultural practices (fertilization, mowing, and irrigation), diseases, pests, intensity of wear conditions, and so forth. Overwinter mortality of cool-season turfgrasses could be very important in northeastern North America, and may significantly reduce the aesthetic value, function, and durability of turfgrass mixtures (DiPaola and Beard, 1992). The presence of endophyte in turfgrasses may also influence the competitiveness between turfgrass species and may modify the dynamic of plant composition. 
The capacity of cool-season turfgrasses to overwinter varies greatly among species and cultivars (Beard, 1973). Creeping bentgrass (Agrostis stolonifera Huds.), a species commonly used for golf putting greens, tolerates the lowest temperature (Gusta et al., 1980). For residential lawns, kentucky bluegrass is the hardiest species, perennial ryegrass is the least hardy, and tall fescue has intermediate susceptibility to freezing stress (Beard, 1973; Gusta et al., 1980). This relatively poor coldtemperature tolerance of perennial ryegrass and tall fescue may prevent their use in pure stands in areas where winter temperatures are very low (Christians and Engelke, 1994). To our knowledge, no study has been published on the effect of cold winter temperatures on Neotyphodium endophyte survival and on how grass-endophyte associations might affect their winter survival and competitiveness in a kentucky bluegrass sward.

We initiated a research program to investigate the potential of overseeding endophytic turfgrasses in established lawns to reduce insect pest problems in the northeastern extremes of North America. The three primary objectives of the present study are 1) to measure establishment and survival of turf-type tall fescue and perennial ryegrass when overseeded (slit-seeded) into existing stands of kentucky bluegrass (because there are no scientific records of this for the far northeastern North American zones); 2) to measure any changes in endophyte infection over time under prolonged winter conditions and prolonged summer day length prevailing in the province of Quebec, Canada; and 3) to measure, at two ecologically different sites, overwinter survival of endophyte-infected and uninfected tall fescue and perennial ryegrass at two different overseeding rates.

\section{Materials and Methods}

\section{Study sites}

The study was conducted at two different sites during 2003, 2004, and 2005 in Boucherville $\left(45^{\circ} 30^{\prime} \mathrm{N}, 73^{\circ} 30^{\prime} \mathrm{W}\right)$, a suburb of Montreal, and in Quebec City $\left(46^{\circ} 49^{\prime} \mathrm{N}\right.$, $\left.71^{\circ} 13^{\prime} \mathrm{W}\right)$. Both locations are within the southern Laurentians ecoregion (EcoRegions Working Group, 1989), which is characterized by a midboreal ecoclimate with warm summers and cold, snowy winters. Mean summer and winter air temperatures are $14{ }^{\circ} \mathrm{C}$ and $-11{ }^{\circ} \mathrm{C}$ respectively. Mean annual precipitation is $800 \mathrm{~mm}$ and $1000 \mathrm{~mm}$ near the cities of Montreal and Quebec respectively. Snow generally covers the ground from mid November to April.

The site located at Boucherville consisted of a new kentucky bluegrass lawn (Poa pratensis $\mathrm{L}$. from a nonaggressive group mainly composed of the cultivars Merion, Baron, and Argyle) established in 2002 using turfgrass sod. The soil was a loam with a $\mathrm{pH}$ of 6.3. Broadleaf weed cover was less than $1 \%$. The experimental lawn, a 10-year-old lawn in Quebec City, was located at Laval University experimental farm, and consisted of a mixture of kentucky bluegrass (47\%), annual bluegrass (Poa annua L.; 14\%), creeping red fescue (Festuca rubra L; 14\%), and bentgrass (Agrostis stolonifera L.; 7\%). The soil was a well-drained shale loam, with a pH of 6.5. In May 2003, weeds were controlled with one application of a selective herbicide (TRILLION, Plant Products Co. Ltd., Quebec). This herbicide, which is a mix of Dicamba (3,6-dichloro-2-methoxybenzoic acid), MCPP [2-(2-methyl-4chlorophenoxy) propionic acid], and 2,4-D (2,4-dichlorophenoxyacetic acid), was applied at the labeled rate to reduce broadleaf cover to less than $5 \%$.

In June 2003 , a total of 16 plots $(2.1 \times 2.1 \mathrm{~m})$ per site were randomly assigned to one of four different treatments, two grass species, and two overseeding rates. Using a commercial overseeder (MATAWAY, O. J Cie., Quebec, which cuts 5.0-cm separated groves through existing cover to insert seeds at the soil level), treatments 1 and 2 were overseeded with 'Bonsai 2000' tall fescue at 90 and $180 \mathrm{~kg} \cdot \mathrm{ha}^{-1}$ respectively. 'Bonsai 2000', a turf-type tall fescue cultivar infected with $N$. coenophialum, provides a more homogeneous lawn when mixed with kentucky bluegrass than common-type fescues (Gilbert and DiPaola, 1985). Treatments 3 and 4 were overseeded with 'Palmer III' ryegrass, a dark-green turf-type cultivar infected with $N$. lolii, at the same seeding rates of tall fescue. High levels of endophyte infection can be obtained with 'Bonsai 2000' and 'Palmer III'. A study by Richmond et al. (2000) in Ohio showed that 38.75 and $77.4 \mathrm{~kg}$ seeds (with more than $60 \%$ infection) per $\mathrm{ha}^{-1}$ provide $35 \%$ of endophyte-infected perennial ryegrass, which is sufficient to reduce pest problems. Because winters in Quebec are more rigorous, higher seeding rates were used in the current study to favor the establishment of a significant proportion of endophytic ryegrass and tall fescue. Each treatment was repeated four times at each site into a randomized complete-block design.

Both sites were exposed to full sun and received three natural fertilizer (9-2-5 Natural Fertilizer; Enviro Sol/Fertichem, Quebec) applications per year $\left(0.34 \mathrm{~kg} \mathrm{~N} / 100 \mathrm{~m}^{2}\right.$ in spring and summer; $0.57 \mathrm{~kg} \mathrm{~N} / 100 \mathrm{~m}^{2}$ in fall) for an annual rate of $1.25 \mathrm{~kg} \mathrm{~N} / 100 \mathrm{~m}^{2}$. This fertilizer was composed of blood, feather, and bone meal, and organic potassium sulfate. The lawns were mowed weekly to a 5to $8-\mathrm{cm}$ height (depending on the growing season period and rainfalls), and clippings were left on the plots. Experimental plots were not irrigated.

\section{Sampling}

Turfgrass establishment. In 2003, the first evaluation to determine the establishment of introduced turfgrass species was done in early October, 4.5 months after turfgrass overseeding. In 2004 and 2005, turfgrass establishment was assessed twice, in May and September, for a total of five evaluations during the experiment.

The ryegrass and tall fescue composition of turf in each plot was determined using a linear pin quadrant modified from Winkworth and Goodall (1962). The quadrant is an 85$\mathrm{cm}$-wide wood frame set on two metal supports, $37.5 \mathrm{~cm}$ high, and has 10 fixed points spaced $85 \mathrm{~mm}$ apart. Leaves touched by the pin at each point are recorded by species. Two quadrants per plot were randomly placed for a total of 20 points per plot. Data are analyzed and presented as the mean percent of grass species per plot for each seeding rate and sampling period.

Endophyte infection. As for turfgrass establishment, the percent of endophyteinfected ryegrass and tall fescue in each plot was determined in Oct. 2003, and in May and Sept. 2004 and 2005. Twenty tillers of only ryegrass or tall fescue per plot were randomly selected and cut at the soil surface, brought back to the laboratory, and tested for endophyte presence. In this instance, a 2-mm cross-section of a tiller was analyzed using a commercial tissue print immunoblot test kit (Agrinostics Ltd. Co., Watkinsville, Ga.). Tissue print immunoblot technique for detection of $N$. coenophialum mycelial proteins was first proposed by Gwinn et al. (1991). The technique was validated by Hiatt et al. (1999), who demonstrated the accuracy of a commercially available, monoclonal antibodybased immunoblot assay (Agrinostics' kit) for the detection of Neotyphodium spp.

Data analysis. Differences over time in turfgrass establishment and endophyte infection were analyzed through repeated-measures analysis of variance using the PROC MIXED procedure (SAS Institute, 2002-2003). The following three effects were tested: site, treatment, and site $\times$ treatment interaction. A priori contrasts were performed to detect differences between grass species and overseeding rates using the PROC GLM procedure. Means were separated using Fisher's protected LSD $(P<0.05)$.

\section{Results}

Turfgrass establishment. In Quebec City, the proportion of tall fescue (range, $11 \%$ to $38 \%$ ) and perennial ryegrass (range, $21 \%$ to $48 \%$ ) plants per plot remained relatively stable throughout the study (Fig. 1A and B). For tall fescue, the number of overseeded plants was highest in Oct. 2003 and then decreased the following spring to remain stable through the end of the experiment (Sept. 2005). For perennial ryegrass, the percent of plants per plot for the $90-\mathrm{kg}$ rate was stable throughout the study, with no difference among all sampling periods. At the $180-\mathrm{kg}$ rate, ryegrass plants were more abundant in Oct. 2003 than in May 2004, May 2005, and Sept. 2005. No difference was observed among the other sampling periods.

At Boucherville, large variations in the proportion of perennial ryegrass (range, 3\% to $39 \%$ ) in experimental plots were observed, whereas tall fescue had a very low rate of establishment (range, $1 \%$ to $19 \%$; Fig. 1C and D). Variation of tall fescue establishment at the $90-\mathrm{kg}$ rate was greater between May 

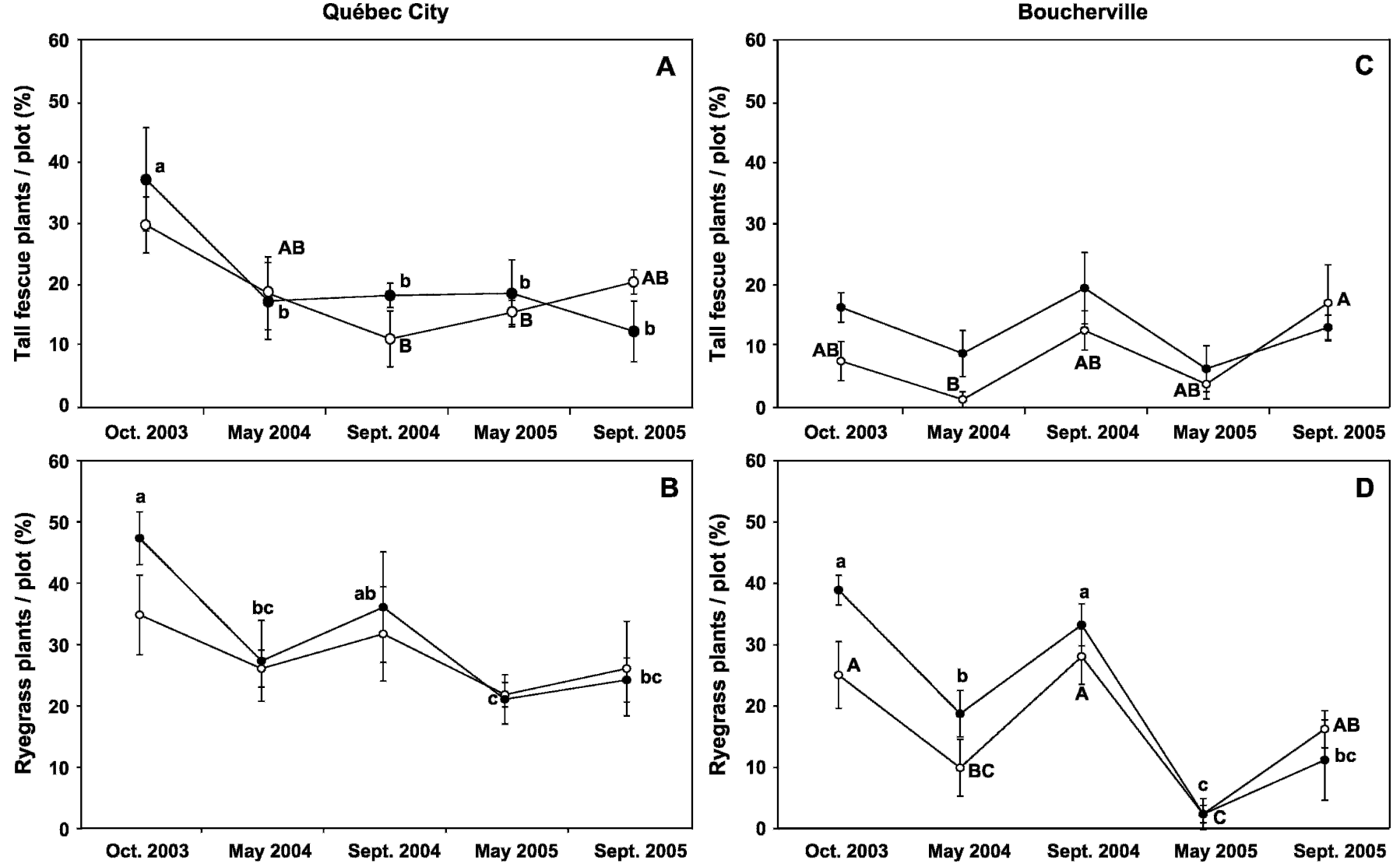

Fig. 1. Percentage of tall fescue and perennial ryegrass plants (mean $\pm \mathrm{SE}$ ) per plot at 90-kg $(\bigcirc)$ and $180-\mathrm{kg}(\bullet)$ seeding rates in Quebec City and Boucherville from Oct. 2003 to Sept. 2005. Plots were overseeded in June 2003. Capital and lowercase letters near the circles indicate differences for 90-kg and 180-kg seeding rates respectively. Means followed by different letters are significantly different [analysis of variance with repeated measures $(\mathrm{F}=16.85, \mathrm{df}=4$, $P<0.05)$ followed by Fisher procedures $(P<0.05)]$.

$2004(1.25 \%)$ and Sept. 2005 (16.9\%). For the $180-\mathrm{kg}$ rate, no difference was detected among the five sampling periods. For perennial ryegrass, the establishment at Boucherville significantly decreased from Sept. 2004 to May 2005 for the two tested rates. However, for the $90-\mathrm{kg}$ rate, the final establishment (in Sept. 2005) was not different from the initial one (in Oct. 2003). At the 180-kg rate, the final establishment was significantly lower than the initial one.

In general, no difference between tall fescue and perennial ryegrass establishment was observed in Quebec City, except in Sept. 2004, when perennial ryegrass was more abundant than tall fescue $(\mathrm{F}=8.70, \mathrm{df}=1$, $P=0.016)$. At Boucherville, perennial ryegrass was more abundant than tall fescue for the first three sampling periods (Oct. 2003: $\mathrm{F}=29.72, \mathrm{df}=1, P=0.0004 ;$ May 2004: $\mathrm{F}=$ 7.66, $\mathrm{df}=1, P=0.02$; Sept. 2004: $\mathrm{F}=25.35$, $\mathrm{df}=1, P=0.0007)$.

Tall fescue and perennial ryegrass had a better winter survival in Quebec City than at Boucherville (site effect: $\mathrm{F}=34.99$; $\mathrm{df}=1$; $P=0.001)$. Tested seeding rates did not influence the establishment of both grass species at both sites (Quebec: $\mathrm{F}=0.61$; $\mathrm{df}=1 ; P=0.44$; Boucherville: $\mathrm{F}=3.17$; $\mathrm{df}=1 ; P=0.08$ ).

Endophyte infection. Overall, endophyte infection in tall fescue was lower $(\leq 10 \%$ at both sites) than expected $(\approx 50 \%)$ based on information provided by the seed supplier (Hortisem and Gloco, Montreal). The proportion of plants infected with Neotyphodium in Quebec City was significantly higher $(P<$ 0.003 ; mean of the two seeding rates, $40 \%$ ) for perennial ryegrass than for tall fescue (mean of the two seeding rates, $2 \%$ ) for all evaluation periods (Fig. 2A and B). A similar trend was observed at Boucherville, with significantly $(P<0.001)$ higher endophyte infection in ryegrass (mean of the two seeding rates, $35 \%$ ) than in tall fescue (mean of the two seeding rates, $2 \%$; Fig. 2C and D).

Endophyte infection in tall fescue decreased rapidly in Quebec City and was no longer detected in Sept. 2004 and May 2005 for the $90-\mathrm{kg}$ and $180-\mathrm{kg}$ seeding rate treatments respectively (Fig. 2A). Similar results for tall fescue were observed at Boucherville, as endophytes were not detected in Sept. 2004 for either seeding rate (Fig. 2C). Percent infected perennial ryegrass plants in both sites remained relatively stable at $\approx 40 \%$ infection throughout the study for the two seeding rate treatments (Fig. 2 B and D) with, at the end of the study, a similar level of infection as observed in Oct. 2003 (site effect: $\mathrm{F}=901 ; \mathrm{df}=1 ; P=0.38$ ). No difference between the two seeding rates was detected for endophyte infection at either site.

\section{Discussion}

Turfgrass establishment. Our results revealed two important ecological attributes of perennial ryegrass var. 'Palmer III' and tall fescue var. 'Bonsai 2000' in northeastern North America. First, both species are well adapted to the climatic conditions prevailing in the province of Quebec, as shown by their persistence over time once established in a lawn. Second, irrespective of the endophyte infection status, tall fescue and perennial ryegrass have the capacity to colonize a mixture of kentucky bluegrass and remain competitive 2 years after overseeding.

In Quebec City, the proportion of tall fescue and perennial ryegrass plants in experimental plots remained fairly constant throughout the study, with no significant variations in abundance between the spring and fall sampling periods. This suggests that drastic changes and extreme climatic conditions prevailing in the winter and the summer do not significantly modify turfgrass survival. It also means that factors other than recurrent overwinter mortality prevent the long-term increase in the proportion of tall fescue and perennial ryegrass in turfgrass polyculture (discussed later).

A different pattern was observed in Boucherville, where tall fescue and perennial ryegrass populations typically declined after 

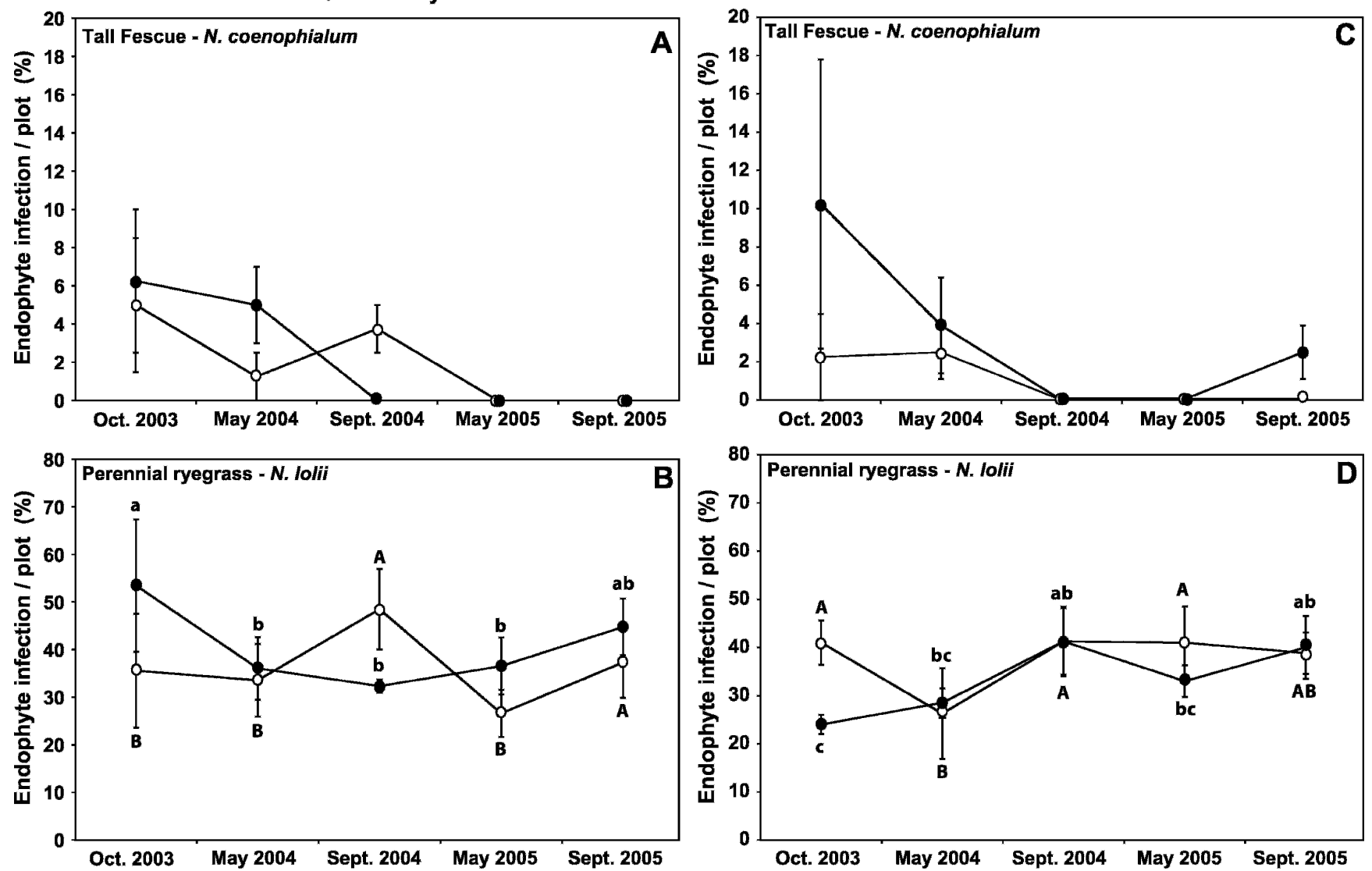

Fig. 2. Percentage of endophyte infection of tall fescue (Neotyphodium coenophialum) and perennial ryegrass plants $(N$. lolii; mean $\pm \mathrm{SE})$ at $90-\mathrm{kg}(O)$ and $180-\mathrm{kg}$ (O) seeding rates in Quebec City and Boucherville from Oct. 2003 to Sept. 2005. Plots were overseeded in June 2003. For perennial ryegrass, capital and lowercase letters near the circles indicate differences for $90-\mathrm{kg}$ and $180-\mathrm{kg}$ seeding rates respectively. Means followed by different letters are significantly different [analysis of variance with repeated measures $(\mathrm{F}=1.51, \mathrm{df}=4, P<0.05)$ followed by Fisher procedures $(P<0.05)]$. No significant difference was observed for tall fescue $(\mathrm{F}=1.51, \mathrm{df}=4, P>0.05)$.
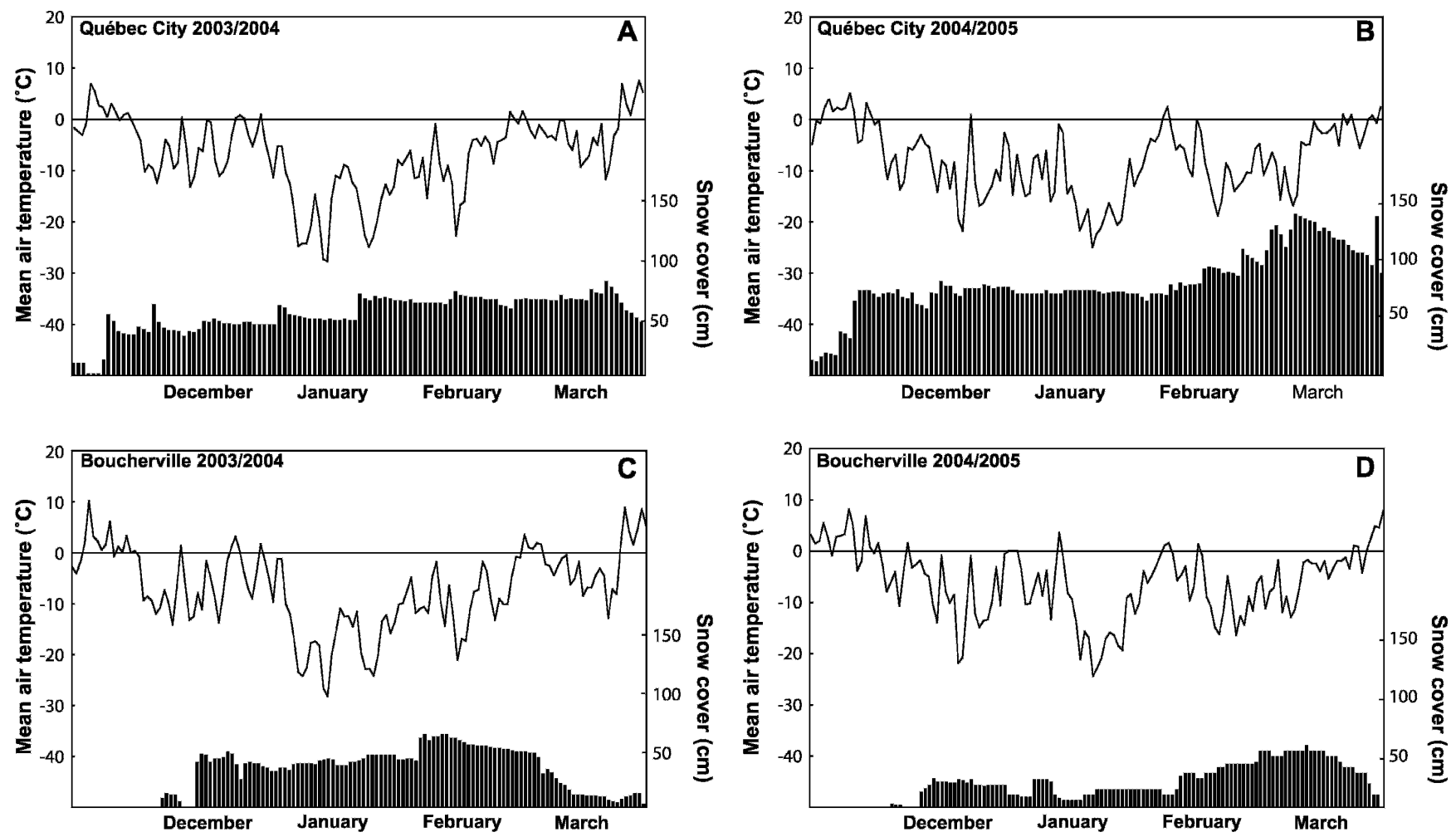

Fig. 3. Daily mean air temperature and snow cover depth in Quebec City and Boucherville for Winter 2003-04 and Winter 2004-05. Data from Environment Canada's weather stations. 
the winter, although Boucherville (Montreal area) is located at a more southern latitude than Quebec City. Overwintering mortality of grass species can be incited by different factors, such as low soil and air temperatures, extreme temperature variations, lack of a natural cover protection, formation of ice, degree of acclimation in fall and deacclimation in spring, and so on (Beard, 1973; Humphreys, 1989; Rajashekar et al., 1983; Ross, 2000). Differences in turfgrass overwintering survival between the two study sites are likely the result of variations in snow cover. Snow provides excellent insulating properties and would protect turf against winter desiccation and low temperatures by reducing the frequency of freezing and thawing episodes (Beard, 1973; Dionne, 2001). Snow cover in Quebec City was thick and present from mid-November to the end of March in Winter 2003-2004 and Winter 2004-2005 (Fig. 3A and B). In contrast, snow cover in Boucherville was much reduced and lasted for a shorter period of time than in Quebec City (Fig. 3C and D). This was more evident in mid Jan. 2005, when snow cover had been considerably reduced by rainfall, thereby exposing turfgrass plants to low temperatures for several days.

The proportion of tall fescue and perennial ryegrass in the spring was much reduced, probably because these plants do not start tillering and producing aboveground biomass as early as kentucky bluegrass (Beard, 1973). The changes in the composition of grass species during the growing season might be the result of enhanced competitiveness of tall fescue and perennial ryegrass over kentucky bluegrass under adverse biotic and abiotic summer conditions, for instance through better ability to compete for moisture in conditions of drought (Hill et al., 1991; Hunt and Dunn, 1993).

There is no indication that the proportion of tall fescue and perennial ryegrass in turfgrass mixed kentucky bluegrass stands would increase notably above $30 \%$ over the years under environmental conditions prevailing in northeastern North America. Doubling the initial seeding rate did not modify substantially the abundance of either tall fescue or perennial ryegrass in experimental plots. A similar pattern was reported in Ohio by Richmond et al. (2000), who observed no difference between different seeding rates of perennial ryegrass overseeded in an established kentucky bluegrass lawn at the end of their experiment. On the other hand, they demonstrated that at lower rates $(45 \mathrm{~kg}$ and $90 \mathrm{~kg}$ ) than those tested in our study, the proportion of perennial ryegrass tillers increased $(28 \%$ to $68 \%)$ over two seasons. Two factors could explain the inability of tall fescue and perennial ryegrass plants to expand when overseeded in an established lawn. First, competition with other plants, mainly kentucky bluegrass, may prevent tall fescue and perennial ryegrass from expanding when overseeded in an established lawn. At Boucherville, competition for seed germination and newly germinated plants was particularly important, because turfgrass density on the 2-year-old kentucky bluegrass lawn was initially higher at this site than at Quebec City. Second, perennial ryegrass and tall fescue are bunch-type grasses (Beard, 1973) that mainly propagate by seed, a mode of colonization that is greatly reduced in a mowed lawn.

Endophyte infection and proportion of endophytic perennial ryegrass plants. To our knowledge, our study represents the first attempt to examine winter survival of endophytes $N$. coenophialum and $N$. lolii under rigorous winter conditions such as those prevailing in the province of Quebec. Neotyphodium coenophialum associated with 'Bonsai 2000' tall fescue, rapidly disappeared at both sites. However, further evidence is needed to assess better the overwintering potential of $N$. coenophialum, because the initial level of infection in tall fescue was very low $(<10 \%)$ in our treatment. The resurgence of endophyte-infected tall fescue in the $180-\mathrm{kg}$ rate treatment in Sept. 2005 at Boucherville may suggest that dormant hyphae of the endophyte have the capacity to survive harsh conditions for prolonged period of time. Alternatively, the disappearance of the endophyte in Sept. 2004 and May 2005 may result from a sampling error, Detection of Neotyphodium-infected plants is problematical when infection levels are very low $(<5 \%)$. Neotyphodium lolii associated with perennial ryegrass has the capacity to survive winter in Quebec. The initial level of endophyte infection remained relatively stable throughout the experiment at both experimental sites.

The proportion of tall fescue or perennial ryegrass plants per plot was multiplied by the corresponding proportion of plants determined to be infected with Neotyphodium to estimate the total proportion of endophytic plants per plot (Fig. 4). Because of the low initial endophytic stem proportion observed at Boucherville, seasonal fluctuations in these proportions appear to be primarily the result of survival of host plants over the seasons. This pattern is different from

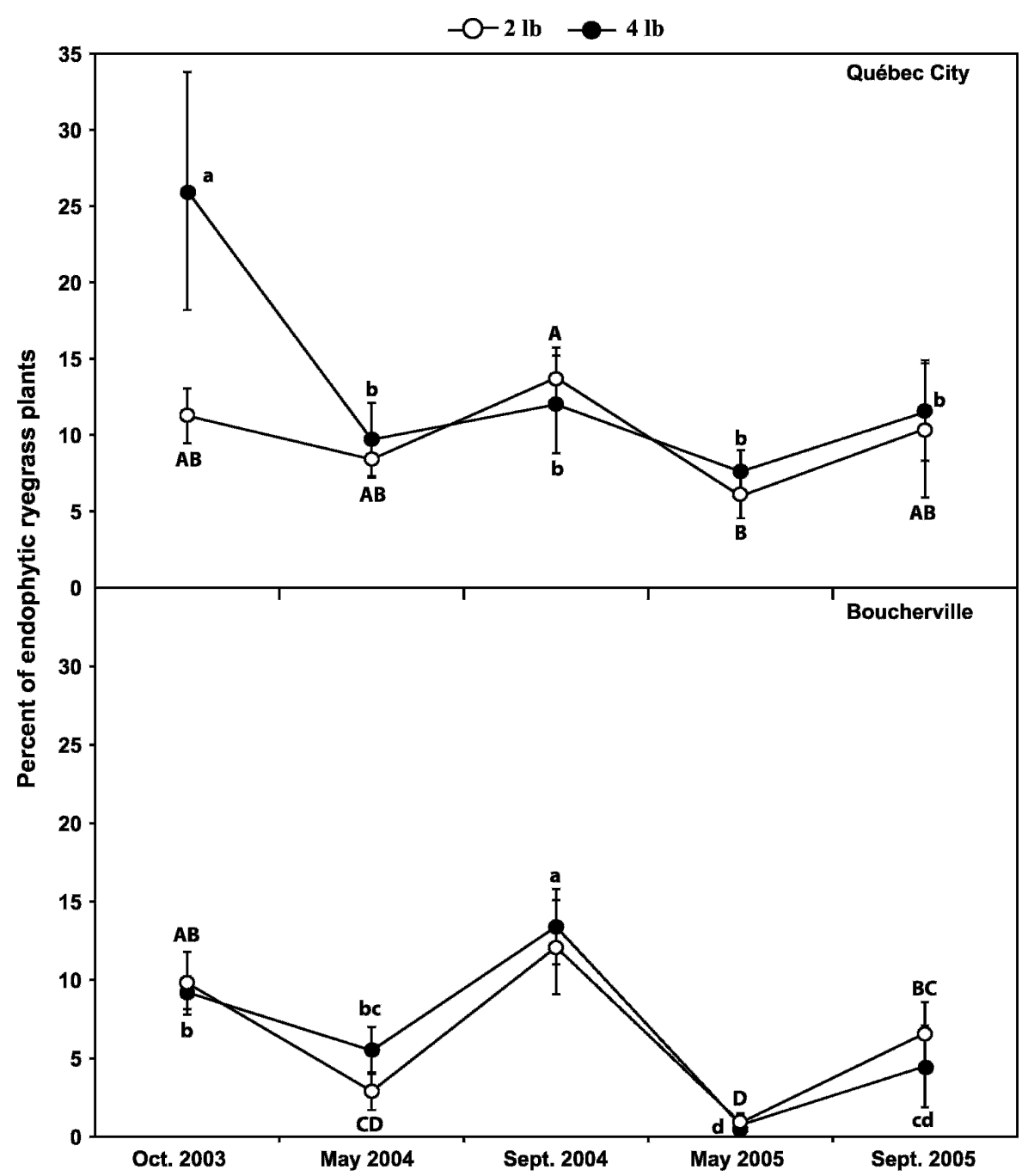

Fig. 4. Proportion (mean $\pm \mathrm{SE}$ ) of endophytic 'Palmer III' ryegrass per plot in Quebec City and Boucherville from Oct. 2003 to Sept. 2005 at $90-\mathrm{kg}(\bigcirc)$ and $180-\mathrm{kg}(\mathbf{O})$ seeding rates. Capital and lowercase letters near the circles indicate differences for $90-\mathrm{kg}$ and $180-\mathrm{kg}$ seeding rates respectively. Means followed by different letters are significantly different [analysis of variance with repeated-measures $(\mathrm{F}=11.70, \mathrm{df}=4, P<0.05)$ followed by Fisher procedures $(P<0.05)]$. 
what was observed in studies conducted in more temperate zones (Richmond et al., 2000; Thompson et al., 1989), where the proportion of endophyte-infected grass increased over time. Such an increase was associated with a better ability of infected plants to survive under stress conditions such as drought and insect herbivory than noninfected plants. These adverse conditions were not observed during the course of our study.

The current study indicates that perennial ryegrass and tall fescue can be used as complementary grass species to kentucky bluegrass in lawns located in regions characterized by rigorous winter conditions and prolonged snow cover. Mixed stands maintain their integrity when snow cover is thick and present for a long period. Overwinter endophyte survival appears to be species specific, with $N$. lolii being able to survive cold winters but not $N$. coenophialum. Moreover, for the perennial ryegrass $-N$. lolii association, competition with kentucky bluegrass is a primary factor limiting the increase over time in the proportion of endophyteinfected plants in a turfgrass mixture. This study is intended as a first step to our understanding of the overwinter ecology of cool-season turfgrass in areas corresponding to the northern limits of their distribution. More information is needed on other grass cultivars and grass-endophyte associations commonly used in North America.

\section{Literature Cited}

Bacon, C.W. 1993. Abiotic stress tolerances (moisture, nutrients) and photosynthesis in endophyteinfected tall fescue. Agr. Ecosyst. Environ. 44:123-141.

Beard, J. 1973. Turfgrass: Science and culture. Prentice Hall, Englewood Cliffs, N.J.

Belesky, D.P., O.J. Devine, J.E. Pallas, Jr., and W.C. Stringer. 1987. Photosynthetic activity of tall fescue as influenced by a fungal endophyte. Photosynthetica 21:82-87.

Brede, A.D. and J.M. Duich. 1984. Establishment characteristics of kentucky bluegrass-perennial ryegrass turf mixtures as affected by seeding rate and ratio. Agron. J. 76:875-879.

Breen, J.P. 1994. Acremonium endophyte interactions with enhanced plant resistance to insects. Annu. Rev. Entomol. 39:410-423.
Carrière, Y., A. Bouchard, S. Bourassa, and J. Brodeur. 1998. Effect of endophyte incidence in perennial ryegrass on distribution, host-choice, and performance of the hairy chinch bug (Hemiptera: Lygaeidae). J. Econ. Entomol. 91:324-328.

Christians, N.E. and M.C. Engelke. 1994. Choosing the right grass to fit the environment, $\mathrm{p}$. 99-113. In: A.R. Leslie (ed.). Integrated pest management for turf and ornamentals. Lewis, London.

Coll, M. and D.G. Bottrell. 1994. Effects of nonhost plants on an insect herbivore in diverse habitats. Ecology 75:723-731.

Dionne, J. 2001. Protection hivernale et tolérance au froid du pâturin annuel (Poa апnиa var. reptans). Faculté des études supérieures, Université Laval, Sainte-Foy, Quebec, PhD Diss.

DiPaola, J.M. and J.B. Beard. 1992. Physiological effects of temperature stress. In: D.V. Waddington, R.N. Carrow, and R.C. Shearman (eds.). ASA-CSSA-SSSA Turfgrass Agron. Monogr. 32.

Dunn, J.H., E.H. Ervin, and B.S. Fresenburg. 2002. Turf performance of mixtures and blends of tall fescue, kentucky bluegrass, and perennial ryegrass. HortScience 37:214-217.

EcoRegions Working Group. 1989. Ecoclimatic regions of Canada, first approximation. Ecological land classification ser., no. 23, Environnement Canada, Ottawa.

Funk, C.R., R.H. White, and J.P. Breen. 1993. Importance of Acremonium in turf-grass breeding and management. Agr. Ecosyst. Environ. 44:215-232.

Gilbert, W.B. and J.M. DiPaola. 1985. Cool season turfgrass cultivars performance in the shade, $\mathrm{p}$. 265-274. In: F. Lemaire (ed.). Proc. 5th Intl. Turfgrass Res. Conf., Avignon, France.

Gusta, L.V., J.D. Butler, C. Rajashekar, and M.J. Burke. 1980. Freezing resistance of perennial turfgrasses. HortScience 15:494-496.

Gwinn, K.D., M.H. Collins-Shepard, and B.B. Reddick. 1991. Tissue print-immunoblot, an accurate method for the detection of Acremonium coenophialum in tall fescue. Phytopathology 81:747-748.

Hiatt, E.E., N.S. Hill, J.H. Bouton, and J.A. Stuedemann. 1999. Tall fescue endophyte detection: Commercial immunoblot test kit compared with microscopic analysis. Crop Sci. 39: 796-799.

Hill, N.S., D.P. Belesky, and W.C. Stringer. 1991. Competitiveness of tall fescue as influenced by Acremonium coenophialum. Crop Sci. 31: 185-190.
Hull, R.J., S.R. Alm, and N. Jackson. 1994. Toward sustained lawn turf, p. 3-15. In: A.R. Leslie (ed.). Integrated pest management for turf and ornamentals. Lewis, London.

Humphreys, M.O. 1989. Assessment of perennial ryegrass (Lolium perenne L.) for breeding: I. Freezing tolerance. Euphytica 41:99-106.

Hunt, K.L. and J.H. Dunn. 1993. Compatibility of kentucky bluegrass and perennial ryegrass with tall fescue in transition zone turfgrass mixtures. Agron. J. 85:211-215.

Latch, G.C.M. and M.J. Christensen. 1985. Artificial infection of grasses with endophytes. Ann. Appl. Biol. 107:17-24.

Malinowski, D.P., D.P. Belesky, and G.C. Lewis. 2005. Abiotic stresses in endophytic grasses, p. 187-199. In: C.A. Roberts, C.P. West, and D.E. Spiers (eds.). Neotyphodium in coolseason grasses. Blackwell Publishing, Ames, Iowa.

Marshall, D., B. Tunali, and L.R. Nelson. 1999. Occurrence of fungal endophytes in species of wild Triticum. Crop Sci. 39:1507-1512.

Rajashekar, C., D. Tao, and P.H. Li. 1983. Freezing resistance and cold acclimation in turfgrasses. HortScience 18:91-93.

Richmond, D.S., H.D. Niemczyk, and D.J. Shetlar. 2000. Overseeding endophytic perennial ryegrass into stands of kentucky bluegrass to manage bluegrass billbug (Coleoptera: Curculionidae). J. Econ. Entomol. 93:16621668.

Richmond, D.S. and D.J. Shetlar. 2000. Hairy chinch bug (Hemiptera: Lygaeidae) damage, population density, and movement in relation to the incidence of perennial ryegrass infected with Neotyphodium endophytes. J. Econ. Entomol. 93:1167-1172.

Ross, J.B. 2000. Evaluation of winter covers for prevention of freezing injury on putting greens, p. 28-32. Prairie Turfgrass Res. Ctr. Annu. Rpt., Alberta, Canada.

SAS Institute Inc. 2002-2003. SAS/STAT user's guide, version 9.1. SAS Inst., Cary, N.C.

Tashiro, H. 1987. Turfgrass insects of the United States and Canada. Cornell University Press, Ithaca, N.Y.

Thompson, R.H., H.A. Freiborg, and B.B. Reddick. 1989. Sampling intensity and timing for detecting Acremonium coenophialum incidence in tall fescue pastures. Agron. J. 81:966-971.

Turgeon, A.J. 1991. Turfgrass management. Prentice Hall, Englewood Cliffs, N.J.

Winkworth, R.E. and D.W. Goodall. 1962. A crosswise sighting tube for point quadrat analysis. Ecology 43:342-343. 